\title{
Petrographic study of selected sculptural works of Jan Michałowicz from Urzędów
}

\author{
Malgorzata Ciosmak ${ }^{1}$ Patrycja Rzęsa ${ }^{2}$ \\ ${ }^{1}$ Institute of Transport, Combustion Engines and Ecology, Faculty of Mechanical Engineering, \\ Lublin University of Technology, e-mail:m.ciosmak@pollub.pl \\ ${ }^{2}$ Faculty of Civil Engineering and Architecture, Lublin University of Technology, \\ e-mail: rzesapatrycja@gmail.com
}

\begin{abstract}
Nowadays, in order to determine whether given rock properties make it useful for specific purposes, the material is examined using relevant test equipment. At the times of Jan Michałowicz, any knowledge in this respect was transmitted by the master to his apprentices, based on the master's experience. The artist used domestic rock raw materials to sculpt monuments commemorating important persons who were his contemporaries.

For the petrographic analysis, the authors selected the most distinguishable works of the artist, which he signed or which are most likely to have been sculpted by him. The authors analysed the materials used by the artist to carve specific elements of his works, as well as rock raw materials in terms of their historical and contemporary properties. Consequently, the petrographic study allowed to describe the rocks in greater detail, as well as their properties useful for sculpture purposes, and their durability. Artistic qualities helped determine the sources of stones used by Jan Michałowicz during his projects. These include the quarries near Pińczów (limestone), Kunów (sandstone), Bolechowice (marble), Żurawno (alabaster) and initially quarries in Hungary. The discussed works of Jan Michałowicz provide firm grounds for acknowledging the artist as the leading co-founder to Polish Renaissance art.
\end{abstract}

Keywords: renaissance, Michałowicz, stone, sculpture, architecture, tombstone, petrography, analysis, rock, marble, alabaster, limestone.

\section{Introduction}

Polish Renaissance architecture and Renaissance art is represented by magnificent structures, paintings and interiors. The beginnings of Polish Renaissance art, falling on the first decade of the sixteenth century, were marked by strong influences from Italy, where renaissance art was later to be developed. The revival period, just like the humanist philosophy, appreciated the value and agency of human beings and promoted the idea of creative freedom. It drew inspiration from Antiquity, at the same not following it in all aspects. The Renaissance developed its own original and unique style, pursuing static and composed forms. It combined compatibility with balance of the components, expressing a specific harmony of the epoch. In artistic disciplines, it defined a clear space, precise outline and evenly dispersed bright light. An important aspect was to render a natural human figure having real-life proportions and including personal features.

Jan Michałowicz from Urzędów was a representative of this epoch considered the most outstanding Polish architect and sculptor of the time. His is famous for his numerous masterpieces, a dozen or so of which have survived to this day. Besides ornamental elements, chapels, 
tenement houses and epitaphs, they mainly include tombstones made of natural domestic or foreign stone, as well as structures and forms resembling the natural ones. In contrast to the late Gothic art, in the Renaissance the deceased were rendered in a somewhat different manner. Michałowicz replaced an inert figure of a dead person with a dynamic rendition full of realism, which was typical of the Renaissance. Works made of stone were encircled with a frame with minor architectural elements enriched with an ornamental relief. Renaissance tombstones sculpted by Michałowicz had mature, perfect forms and appeared in places of unique, distinct and sacred significance, such as e.g. inside cathedrals or at the Wawel Hill which at that time was the centre of authority and affluence.

Besides the widely known and used granite, Hungarian and other marble stones, he added the local alabaster, red marble from Świętokrzyskie region of different hues, sandstone and limestone to the list of materials used in his minor architecture and stone sculptures. Petrographic diversity of the stone materials is highly interesting and became the major focus of this paper.

\section{Biography of Jan Michałowicz from Urzędów}

Jan Michałowicz was born around 1530. He came from the Lublin region, from the royal town of Urzędów, which was granted a town charter in 1405. He was an outstanding sculptor and architect of his time, and his artistic activity coincided with that of Jan Kochanowski, the greatest Polish renaissance poet. And “(...) just like Kochanowski who, being familiar with the earlier and the then foreign literary works, produced his own original works, Michałowski, inspired by foreign fashions, sculpted his highly distinguished works. (...)" [1]. He pursued his own artistic path; in his works, he realized his own original concepts, self-conceived motifs and was inspired by domestic art. He skilfully combined spatial and visual elements to create architectural works. He started his sculpture education in his home town of Urzędów. At that time, Urzędów was a very wealthy town, therefore also the Michałowicz bourgeoisie family were quite affluent. They could afford to educate their children in the best schools and art ateliers. In Cracow, which became the place of his permanent residence, Michałowicz was initially influenced by Jan Maria Padovano and the sculpting skills of Giovanni Cini. However, inspired by Italian and Dutch movements, he finally developed his own style and design, as well as the range of typical materials he would use. He had a strong position among Polish artists in this respect. "(...) He gradually enriched the portfolio of his architectural and sculpting compositions, and each work contributed to his development as an artist. (...)" [2]. Besides his sons, he trained many craftsmen helping them develop excellent sculpting and architectural skills; they later became acknowledged artists accepting commissions in Poland and abroad. The surviving works of Jan Michałowicz primarily include tombstones of affluent individuals, authority representatives and church leaders. His last commission was the erection of St. Victoria's chapel in the Łowicz cathedral where he also produced a richly carved tombstone of primate Jakub Uchański who deceased in 1581. During the fall of the Polish-Lithuanian Commonwealth, these works were dismounted and stripped of their ornaments. Jan Michałowicz died in 1583 in Lowicz, and he is believed to be buried in the underpass of St. Victoria's chapel which he built and adorned. On the wall next to the rebuilt tombstone of primate Uchański which was moved to another place, there is a house mark in the form of a cross combined with a framing square (Pic. 2) and a plaque. Carved in marble (Pic. 1), it honours Michałowicz as the "Polish Praxiteles". The words [3] were most probably written by the most distinguished Polish poet of the time, Jan Kochanowski, who was his friend. 


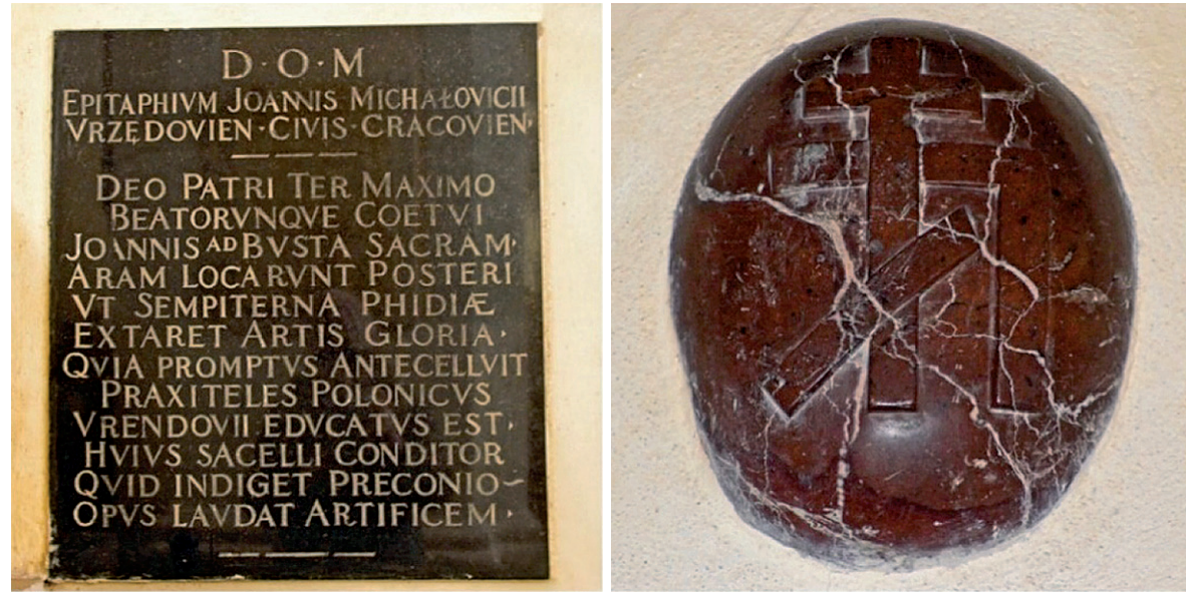

Pic. 1. An epitaph honouring Jan Michałowicz

Pic. 2. House mark of Jan Michałowicz from Urzędów

Due to renovation works conducted in the Łowicz cathedral and inability to photograph the works associated with Jan Michałowicz, the photos are published by courtesy of canon Stanisław Majkut STL, resident of the Assumption of the Blessed Virgin Mary church in Łowicz.

Inscription in Latin:

DEO PATRI TER MAXIMO

BEATORUNQUE COETUI JOANNIS AD BUSTA SACRAM ARAM LOCARUNT POSTERI UT SEMPITERNA PHIDIAE EXTARET ARTIS GLORIA QUIA PROMPTUS ANTECELLUIT PRAXITELES POLONICUS URENDOVII EDUCATUS EST HUIUS SACELLI CONDITOR QUID INDIGET PRAECONIO OPUS LAUDAT ARTIFICEM.
English translation:

TO THE TRICE HOLY GOD

AND THE FELLOWSHIP OF SAINTS

THE DESCENDANTS OF JOHN ERECTED THIS CONSECRATED ALTAR ON HIS TOMB

TO REVEAL THE IMMORTAL GLORY OF

THE DESCENDANT OF PHIDIAS,

POLISH PRAXITELES WHO GREW UP

IN URZĘDÓW, THE CREATOR

OF THIS CHAPEL, WHOSE ART

RAVISHED OUR HEARTS.

WHEN NO WORDS CAN GIVE DUE PRAISE, IT IS THE WORK THAT DULY PRAISES ITS MASTER.

The epitaph of the Latin language was translated by the canon priest dr. Zbigniew Wójtowicz.

\section{Rock raw materials used in artworks of Jan Michałowicz from Urzędów}

It was common practice to honour extraordinary church and civic leaders by erecting monuments or exquisite tombstones. Affluence and access to materials, as well as current fashions determined the scope of works and selection of a given artist. Works of Jan Michałowicz from Urzędów were produced at the meeting point of fashions from the passing 
and coming epochs. With the appearance of Italian art at royal courts in Europe, Poland saw the arrival of royal marble stones. These were red marbles extracted from quarries near Hallein, a town located south of Salzburg. The well-known pits in Adnet, Puch, Oberalm offered speckled marble stones with their characteristic patterns and colours. These included red marbles, referred to as rostcheck, yellow marble stone - scheck and cherry-coloured rottropf stone. The Hungarian marble mined in Sziszke, a stone pit located between Buda and Esztergom, and at the foot of the Gerecse mountains [4], was highly popular among sculptors. The fashion of using the "royal purple" quickly caught on in Cracow. This rather expensive raw material was imported from abroad, or strictly speaking from Hungary. However, considerable transport costs and the conquest of the Kingdom of Hungary by the Ottoman Empire between 1540-42, made artists look for domestic rock materials, coming from the same geological formations. Concurrently at that time beds of Devonian limestone were discovered in the workings of Bolechowice range, the Czerwona Góra mountain (also referred to as Jerzmaniec) and Grzbiet Zelejowski (Zelejowa crest). For the entire sixteenth century, which is exactly the period of Jan Michałowicz's artistic activity, mountainsides of Czerwona Góra were an acknowledged source of Sigismund (Zeichstein) conglomerates [5].

Devonian limestone from the Bolechowice range, also referred to as Bolechowice marble stone, is the Middle Devonian thick-layer limestone. Middle Devonian recorded in Poland includes the Eifelian $-393.3 \pm 1.2$ million years and the Givetian $387.7 \pm 0.8$ million years back. At that time, the territory of Poland was below the sea level, with deposits from dying organisms forming at the sea floor. Across the Northern Hemisphere, intense erosion of mountain chains elevated above the sea level was taking place. Consequently, beds of red-coloured sandstone and conglomerates were formed [6]. In Zechstein, sedimentary rock layers were of maritime origin. The alternate marine transgressions and regressions enhanced precipitation of gypsum, potash and rock-salt from concentrating solutions, generally referred to as evaporite cyclothems. Claystones, mudstones, limestones and dolomites were formed at the same time [7]. Devonian limestone referred to as the "royal marble" is an organodetritic limestone with compact structure (clastic organic). It has a dymorphic internal structure. Within a single block, there is the soft and hard phase. The soft phase consists of secretive structures in the form of calcite veins and clay and iron concentrations. The compact phase was formed from diversified cryptocrystalline formations of very fine particle matter, as well as bioclasts and lumps with higher levels of crystallinity (calcite veins in breccia zones). Intensity and depth of red Bolechowice marble stone results from iron oxide and hydroxide content (goethite $\mathrm{Fe}_{2} \mathrm{O}_{3} \cdot \mathrm{H}_{2} \mathrm{O}$ being the prevailing compound). Brown and dark brown colour is produced owing to an admixture of limonite $\left(2 \mathrm{Fe}_{2} \mathrm{O}_{3} \cdot 3 \mathrm{H}_{2} \mathrm{O}\right)$. Specific properties of the rock material after it is extracted from the ore are also important for the producer of a sculpted element. They can change in terms of their colour, resistance to environmental conditions, as well as mechanical properties. Limonite is transformed into siderite $\mathrm{FeCO}_{3}$, and ferric hydroxide $\mathrm{Fe}(\mathrm{OH})_{3}$ [8]. The royal marble stone which is easily polished ranges from coffee beige to claret brown. Close scrutiny of the rock material revealed presence of numerous sponge species - twig-like and knob like forms of Amphiphora, stromatoporoids, Rugose corals, Megadolon molluscs and Loxonema gastropods. The structure is cut through by veins of white and pink calcite [9]. Properties of the discussed rock material make it perfect for production of linings, cladding, floors, ornamented portals, window frames and as a sculpting material. Owing to its non-homogeneous structure, colour and pattern, the material has the demanded decorative qualities allowing to create works devoted to important historic figures. The quarry in Bolechowice allowed to mine blocks 
of $100 \times 75 \times 40 \mathrm{~cm}, 160 \times 100 \times 50 \mathrm{~cm}$, if not larger. Block size allowed to make sculptures reflecting real dimensions of an adult, to the satisfaction of Jan Michałowicz. From the Middle Ages and Renaissance to the present day, the properties of the rock material have not changed; it has density of $2.7 \mathrm{~g} / \mathrm{cm}^{3}$, water absorption of $0.12 \%$, dry air compressive stress of $100.00 \mathrm{MPa}$, with no reservations after freezing, Bohme disc dry air abrasion wear of $0.65 \mathrm{~cm}$. These properties facilitated working and polishing of ornamental elements. However, carbonate rocks in atmospheric conditions changing with each season, gradually lost their polish, therefore Jan Michałowicz used them only in interior applications [5].

Another rock material used by the sculptor was the Pińczów limestone. It was named after the oldest limestone excavation site. Besides Pińczów, this limestone was mined in Trzonów, Kików and Szydłów. These quarries allowed to mine the material on a very large scale. This was possible due to easy processing, availability and thickness of these light Tertiary limestone of up to a few dozen meters [10]. Pińczów and the surrounding areas are located in the Świętokrzyskie region which used to be a profitable centre of limestone distribution. Cost of acquisition and transport, quite important during production of the works of art, were much lower when compared to prices of materials imported from abroad. Pińczów limestone mined from ores has not changed its properties for the past few centuries; it was highly resistant to frost, which made it excellent material for the production of ornaments and structural components, for indoors and outdoors applications. It was so easily processable that it could be sculpted only with woodcarving tools. Over time, ornaments exposed to the changing weather conditions were becoming water repellent, harder and displayed greater tensile strength. This was due to a rare phenomenon of covering the rock surface with a $4 \mathrm{~mm}$ deep layer of a kind of patina that protected the rock from water penetration of its porous structure. After evaporation of moisture from the inside of the material and filling the empty spaces with crystallizing calcite, a crystalline skeleton was produced, reinforcing the rock structure. In this manner, the initially soft material improved its durability $[11,12]$. The Pińczów limestone is a sedimentary rock containing over $50 \%$ of $\mathrm{CaO}$ (51.6-4.8). It was formed in the lower Tortonian, bordering with the Helvetii and Sarmatian. In the Tortonian, Lithotamnium limestone was formed, whereas the Sarmatian saw the formation of arenaceous organodetritic limestone. For his sculptures, Jan Michałowicz used finer-grained limestone of organodetritic origin, which due to its compact structure, was easily processed and had high mechanical wear resistance. Clastic, sand-resembling structure of the rock most probably served as the base for Pińczów limestone, often mis-denominated as sandstone. It had density of $2.70 \mathrm{~g} / \mathrm{cm}^{3}$, porosity of $36.67 \%$, water absorption of $15.45 \%$, dry air compressive strength of $8.9 \mathrm{MPa}$ and wet compressive strength of $6.1 \mathrm{MPa}$ and Bohme disc dry air abrasion wear of $2.05 \mathrm{~cm}$. Exploration of domestic rock materials, as well as willingness to diversify the works and facilitate raw material processing led to the introduction of a new rock material - alabaster. Geologically, alabaster includes varieties of two different minerals. The first variety is calcite; it is very hard which made it difficult to carve and serve as the sculpting material. The second variety used for many centuries, is a type of gypsum (hydrous sulfate of calcium). Its colour ranges from white, milk-white, beige, sometimes greenish to nearly black, and it is semi-transparent. The variety of colours results from silt admixtures in the emerging rock, and from the way in which light travels through the rock structure. Softness of the material (2 according to the Mohs scale of mineral hardness) makes it easier to handle, however on the other hand makes the material very susceptible to mechanical damage and poorly resistant to environmental conditions. This makes it easy to scratch, even with a nail; this feature distinguishes alabaster from marble which is 
at times similar, yet considerably harder. Nowadays, it is mined from the ore in Łopuszcza Wielka near Przeworsk, whereas in the Middle Ages and the Renaissance, the most renown alabaster was excavated near Stanisławów (now, Ivano-Frankivsk, Ukraine) and Żurawno settlement. Until this day, blocks obtained from this quarry range up to $6 \mathrm{~m}^{3}$. The first documented mining of alabaster at this site was recorded in 1560; at that time in the masonry jargon it was called the Ruthenian marble, Polish marble or Lviv marble. Just like in the case of other well-known deposits, it was formed in the Miocene along the Carpathian overthrust zone [13]. Jan Michałowicz from Urzędów is believed to be the first sculptor who dared to use alabaster to carve statues and ornamental elements during the Renaissance. From a single block of alabaster, he sculpted the figure of bishop Filip Padniewski, as well as columns and fine details of his tomb. In this manner, he obtained the effect of smoother lines of the robe. Some of his works were carved in sandstone. As a result of historic and petrographic analyses, we can indicate the very likely sites of mining the stone used in the production of this artwork. Sandstone from Lower Silesia and the Świętokrzyskie region have been taken into account, however considering the times of Jan Michałowicz's activity, quarries in the Świętokrzyskie region were the closest to the location of the artworks. Considering the properties of sandstone from Szydłowiec and Kunów areas, being of the same age and having similar rock structure, this material was most likely used in tombstones of Urszula Leżeńska in Brzeziny and of Wolski brothers located in the Warsaw cathedral. Kunów sandstone is white to cream, light grey and grey-white. It gets slightly darker when exposed to environmental conditions. It is frost-resistant, having compressive strength ranging from $82-96 \mathrm{Mpa}$, abrasion wear of $0.36-4.7 \mathrm{~cm}$, density ranging $1.82-2.58 \mathrm{~g} / \mathrm{cm}^{3}$, changing porosity $3-28.2 \%$, and water absorption ranging $3.2-14.1 \%$. Under changing weather conditions, it gets covered by a layer of patina becoming greyish, which is clearly observable in artworks sculpted by Jan Michałowicz from this stone. Sandstone mined in the Kunów area was formed from sharp-edged quartz sand grains bound with silica binder and an admixture of silty substance. It was formed in the early Jurassic, Lias, Drzewice series (210-180 million years ago) from eroded crystalline rocks deposited in inland wetlands created by rivers and lakes. It is long-bed and finer-grained sandstone, well-sorted. These properties make it highly useful for creating fine minor ornaments [14].

Diagenetic and petrographic classification of sedimentary rock materials used by Jan Michałowicz for his artworks:

Sedimentary rocks:

- carbonate

1 - limestones

- ordinary

- marble

- marl

- chalk

- lacustrine limestone

$2-$ marl

3 - opoka (type of carbonate-silica rock)

4 - gaize (type of siliceous sedimentary rock)

5 - dolomite

- sulfate

1 - gypsum

2 - alabaster 
- clastic

1 - porphyritic tuff

2 - greywacke

3 - sandstone

- ordinary

- quartzite

- arkose

4 - sand

5 - natural aggregates

6 - filtration gravels

7 - glacial erratic

\section{Works of Jan Michałowicz from Urzędów}

Jan Michałowicz has clearly evolved as an artist, from definitely sophisticated works offering abundant details, to less complex compositions. His artistic development may be observed in the surviving works, six of which were affixed with his full name, with IMUF abbreviation or with his house mark. Ornaments play the major role in his works; they facilitate identification of works lacking his signature or those where his signature has not survived. They prevail over the actual structure. His works contain very few planes without any ornaments and the border between ornamental motifs and the structure is very smooth. Examples include his first tombstones sculpted for such bishops as Benedykt Izdbieński in Poznań (1557-1560), (Pic. 3) and Andrzej Zebrzydowski in Cracow (1560-1563), (Pic. 4), as well as the lintel in the portal of the former Florian Mokrski Palace coming from that time, located by 18 Kanonicza Street in Cracow (Pic. 5). In his later works, the artist clearly obtains some balance between the form and its ornamentation. This shift can already be observed in the tombstone of Urszula Leżeńska located in Brzeziny, however its exact date is not known (Pic. 20). Disassembly and re-assembly does not reflect the original artistic assumption. Multiple architectural and sculpture commissions contributed to his extensive professional experience. In the surviving fragment of the tombstone of bishop Filip Padniewski located at the Wawel Hill and carved between 1572-1575, the structure prevails over ornaments, exhibiting elegance and original design (Pic. 6). This is due to the structure-focused approach and the use of new materials (rock raw materials) of domestic provenance.

It has been confirmed by history that virtually all tombstones were reworked many times after the death of their designers, which led to impoverishment of the details and size. The reasons for this included change in the current fashion followed by dismemberment when all decorations were removed according to a specific plan. Radical changes occurred also during acts of war. An excellent example of such change are the surviving remains of the tombstone of Wolski brothers in the Warsaw cathedral (Pic. 30). The only surviving elements include partially reconstructed figures of the brothers, whereas other elements of this sumptuous tombstone were destroyed during Warsaw bombings. 

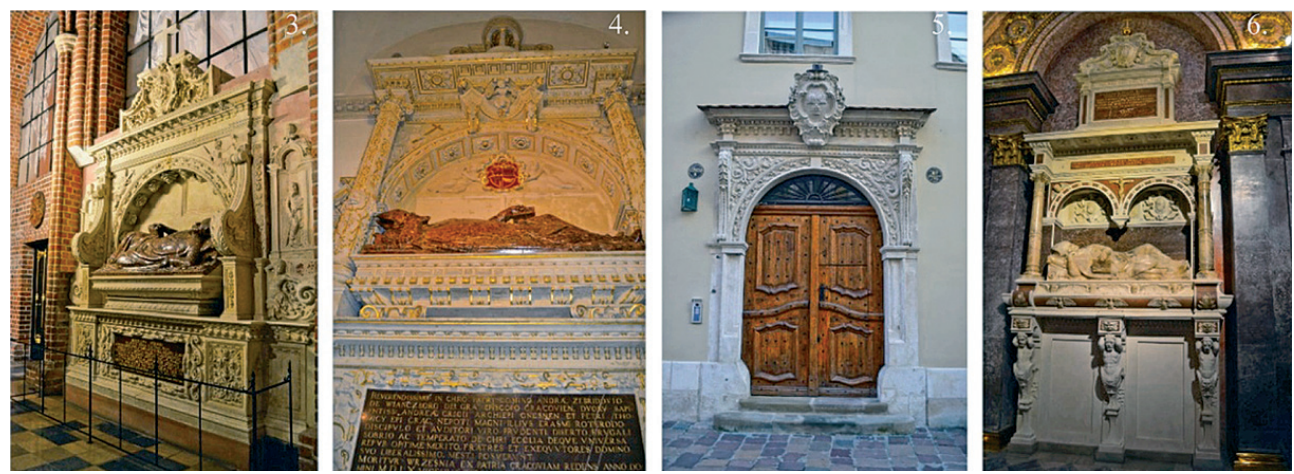

Pic. 3. Tombstone of bishop Benedykt Izdbieński in Poznań (155401560). (Pic. P. Rzęsa)

Pic. 4. Tombstone of bishop Andrzej Zebrzydowski in Cracow (1560-1563). (Pic. P. Rzęsa)

Pic. 5. Lintel in the portal of a historic tenement house by 18 Kanonicza Street in Cracow. (Pic. P. Rzęsa)

Pic. 6. Tombstone of bishop Filip Padniewski in Cracow at the Wawel Hill (1572-1575). (Pic. P. Rzęsa)

\subsection{Tombstone of bishop Benedykt Izdbieński in Ostrów Tumski cathedral in Poznań}

The tombstone of bishop Izdbieński was made of the following types of rock: the main figure was carved in the red Bolechowice marble (Pic. 7, 10), whereas the surroundings and other elements were made of white Pińczów limestone (Pic. 8, 9). The plaque was carved in red marble, most probably the Hungarian marble, which can be partially seen in picture 3 .
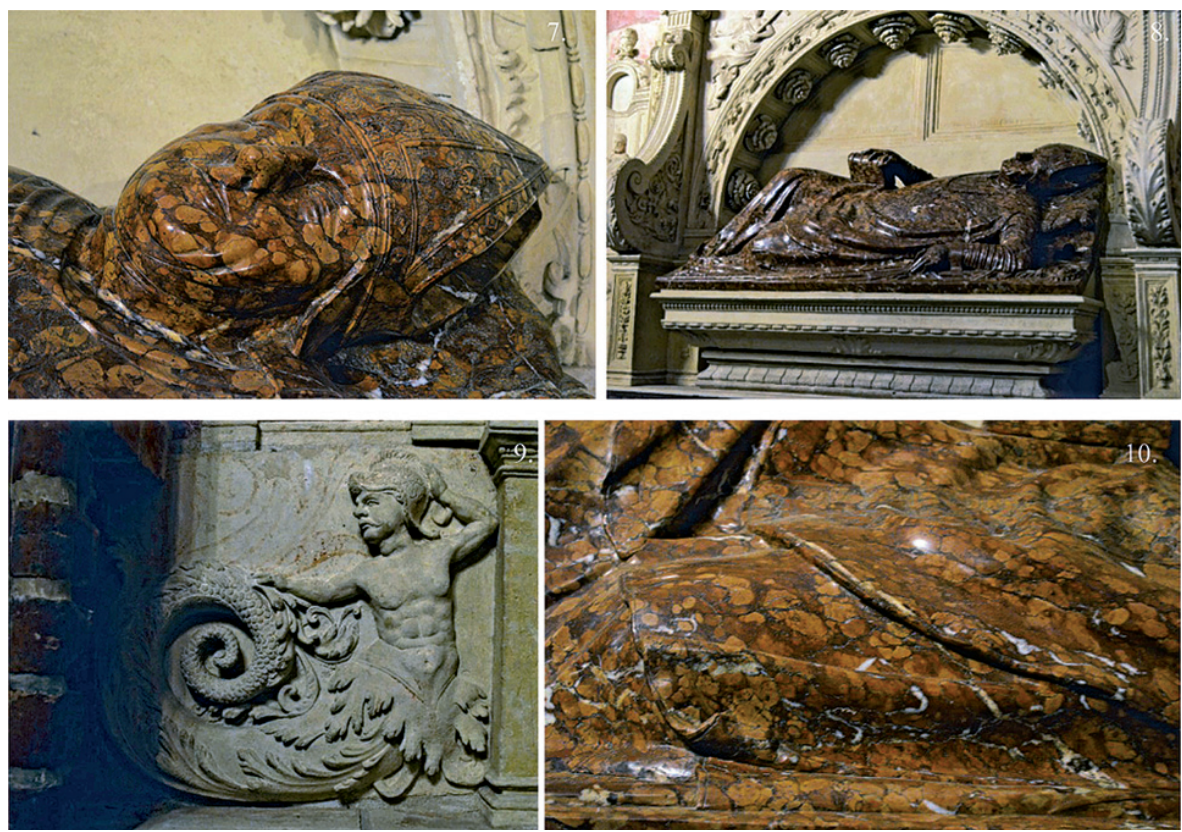

Pic. 7. Head from the figure of bishop Izdbieński. (Pic. P. Rzęsa)

Pic. 8. The figure inside the setting. (Pic. P. Rzęsa)

Pic. 9. Ornamental element. (Pic. P. Rzęsa)

Pic. 10. Close-up on the material. (Pic. P. Rzęsa) 


\subsection{Tombstone of bishop Andrzej Zebrzydowski in The Wawel Royal Cathedral of St. Stanislaus B.M. And St. Wenceslaus M. in Cracow}

The main figure in the tombstone of bishop Andrzej Zebrzydowski was carved in red Bolechowice marble (Pic. 12). The setting surrounding the figure was made of Pinczów limestone (Pic. 11), whereas the plaque is most probably the Bolechowice marble; figure of the bishop is presented below in picture 4 .
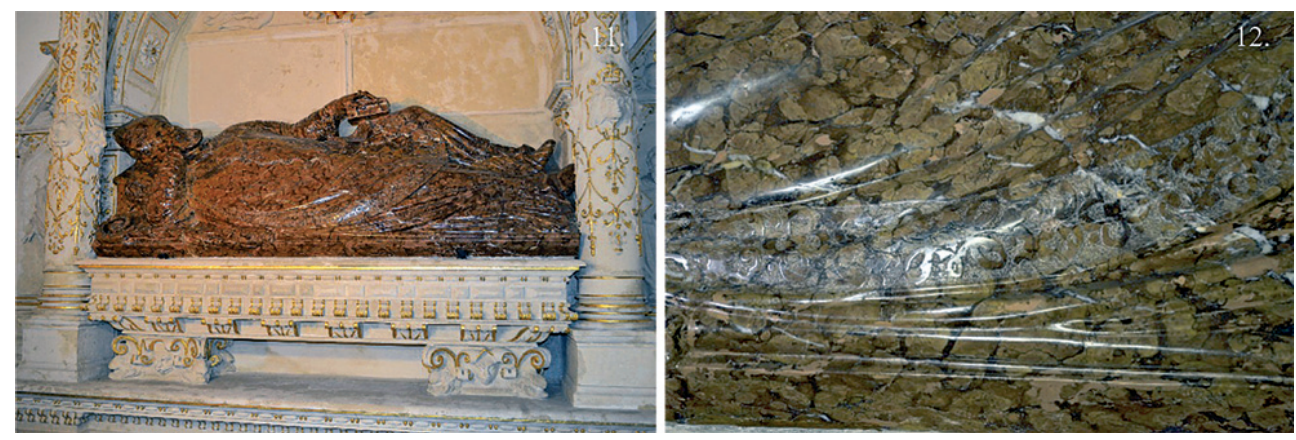

Pic. 11. Figure of bishop Zebrzydowski with the setting carved in Pinczów limestone. (Pic. P. Rzęsa)

Pic. 12. Close-up on the rock structure and a richly ornamented fragment of the robe. (Pic. P. Rzęsa)

\subsection{Tombstone of bishop Filip Padniewski and the chapel of Potocki family in The Wawel Royal Cathedral of St Stanislaus B.M. And St Wenceslaus M. in Cracow}

The monument to the bishop and the plaque were carved by Michałowicz in the red marble, whereas the architectural and decorative frame/setting was made of sandstone. Bishop Padniewski's figure was carved in alabaster. As it was only possible to acquire small rock blocks, the sculpture was made of three parts, which is reflected in the non-continuities in the stone microstructure (Pic. 13). Columns and angels were carved in the same material (Pic. 14), just like the eagles, other small details and the cross. The setting of the tombstone was carved in Pinczów limestone, the background facing of the Bolechowice marble, whereas the plaque of the red Hungarian marble. The remaining ornaments were made of redcoloured stucco (Pic. 6). Attention should also be paid to a number of ornamental elements exterior to the chapel (Pic. 17). After it was rebuilt, the exterior wall behind the columns and the baldachin over the exit from the crypts featured a medallion with the artist's house mark made of the Pinczów limestone (Pic. 18). Originally, it was in set in the roof lantern over the dome. The same material was used to carve the corbles located underneath the dome planform, whose off-white colour clearly contrasts the background. 

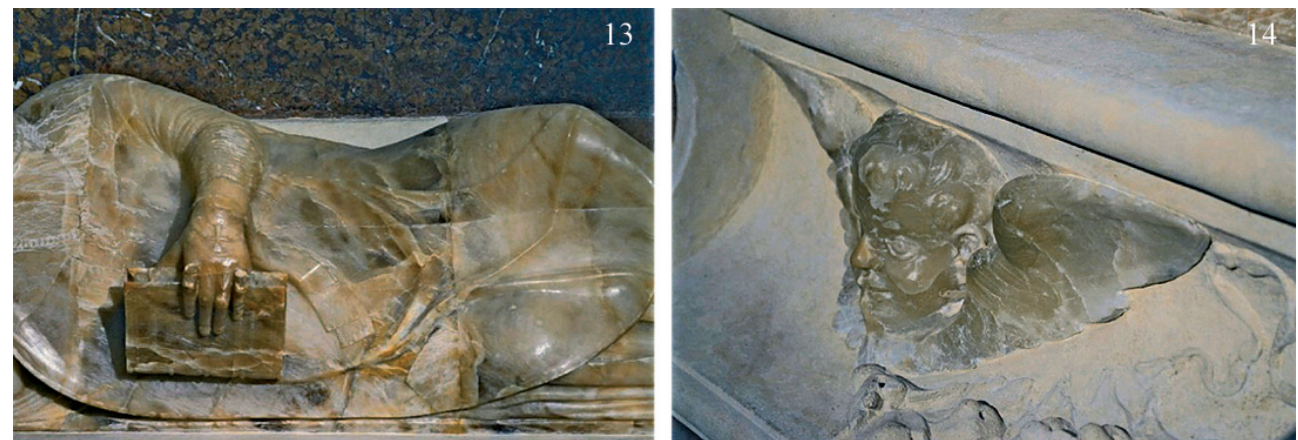

Pic. 13. Figure of bishop Padniewski. (Pic. P. Rzęsa)

Pic. 14. An angel - an ornamental element. (Pic. P. Rzęsa)
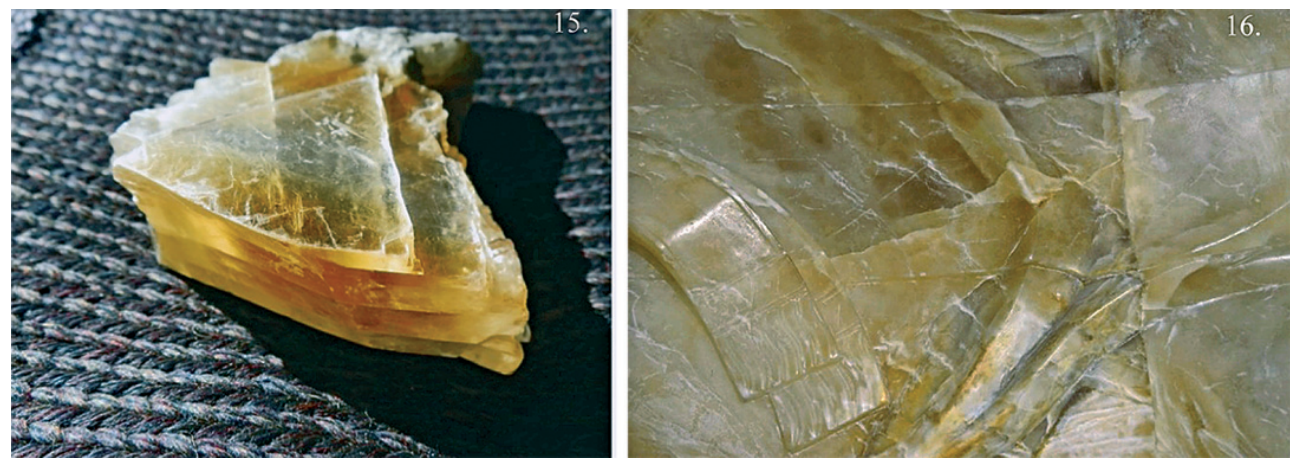

Pic. 15. Alabaster - material in which the artist carved the monument to bishop Padniewski. (Pic. M. Ciosmak)

Pic. 16. Fragment of the material used to sculpt the figure. (Pic. P. Rzęsa)
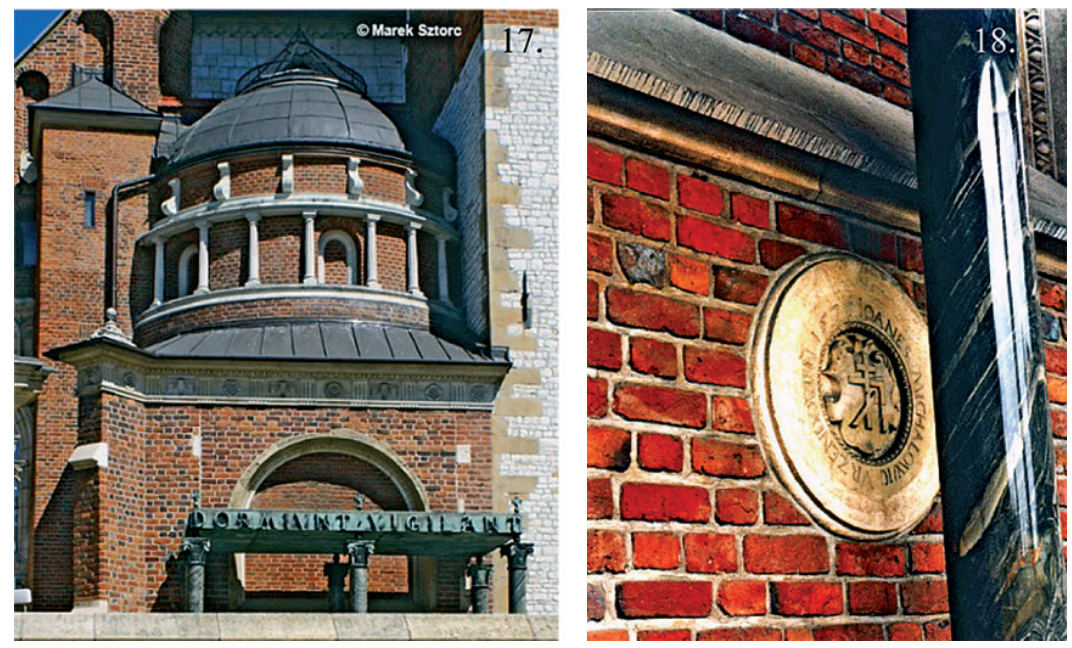

Pic. 17. Bishop Padniewski's chapel - view from the outside. (Source: http://www.zabytkowekoscioly. net/index.php/malopolskie/197-krakow-katedra-ss-waclawa-i-stanislawa)

Pic. 18. Medallion with the artist's house mark. (Pic. M. Ciosmak) 


\subsection{Tombstone of bishop Jakub Uchański and St. Victoria's chapel in the Assumption of the Blessed Virgin Mary and St. Nicholaus cathedral in Lowicz}

Michałowicz combined two blocks of alabaster to carve the figure of bishop Uchański, as it was difficult to acquire a properly large block of the material. The remaining white elements were carved in Pińczów limestone.

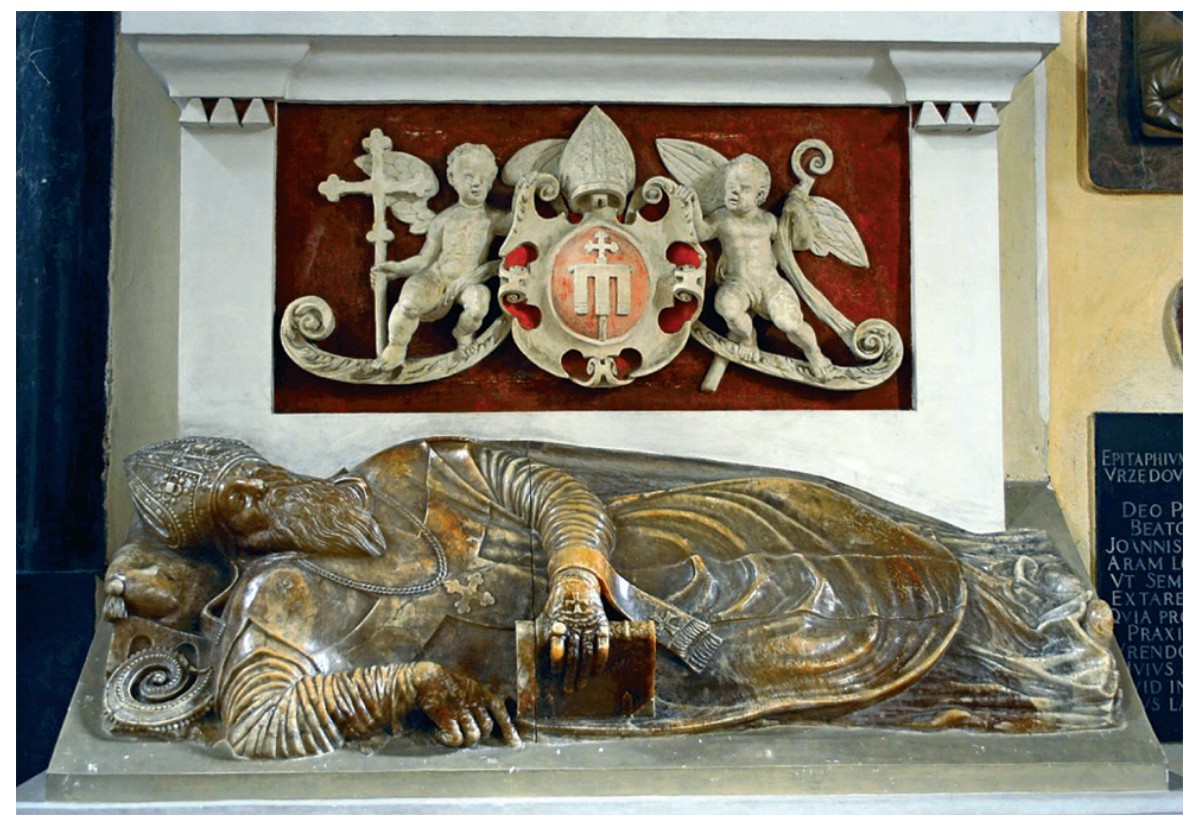

Pic. 19. Tombstone of bishop Uchański in Łowicz. Due to rehabilitation works conducted in the Łowicz cathedral and inability to photograph the work, the photo was published by courtesy of canon Stanisław Majkut STL, resident of the Assumption of the Blessed Virgin Mary church in Łowicz on 15 December 2017

\subsection{Other works of the artist}

\subsubsection{Lintel - 18 Kanonicza Street in Cracow}

Lintel of the Renaissance entrance portal of the former Florian Mokrski Palace (Pic. 20), was carved by Michałowicz during reconstruction of the building in the second half of the sixteenth century, which was initiated by canon Marcin Izdbieński in a not clearly defined period of time (most probably between 1560-1563). The lintel was carved in the Pińczów limestone mined in quarries located in the Świętokrzyskie region. Ornaments are very similar to those found in the tombstone of bishop Zebrzydowski. The archvolt of the portal is a Dutch scroll-like decoration (Pic. 21). Volutes on both sides of the portal, can be found in the earlier work of the artist, that is in the tombstone of bishop Izdbieński (Pic. 22). Jambs come from the first half of the sixteenth century and they were not made by Jan Michałowicz. The cartouche with the coat-of-arms was carved in the eighteenth century [2]. However, the rock structure indicates that it originated from the same quarry as the remaining part of the lintel. 

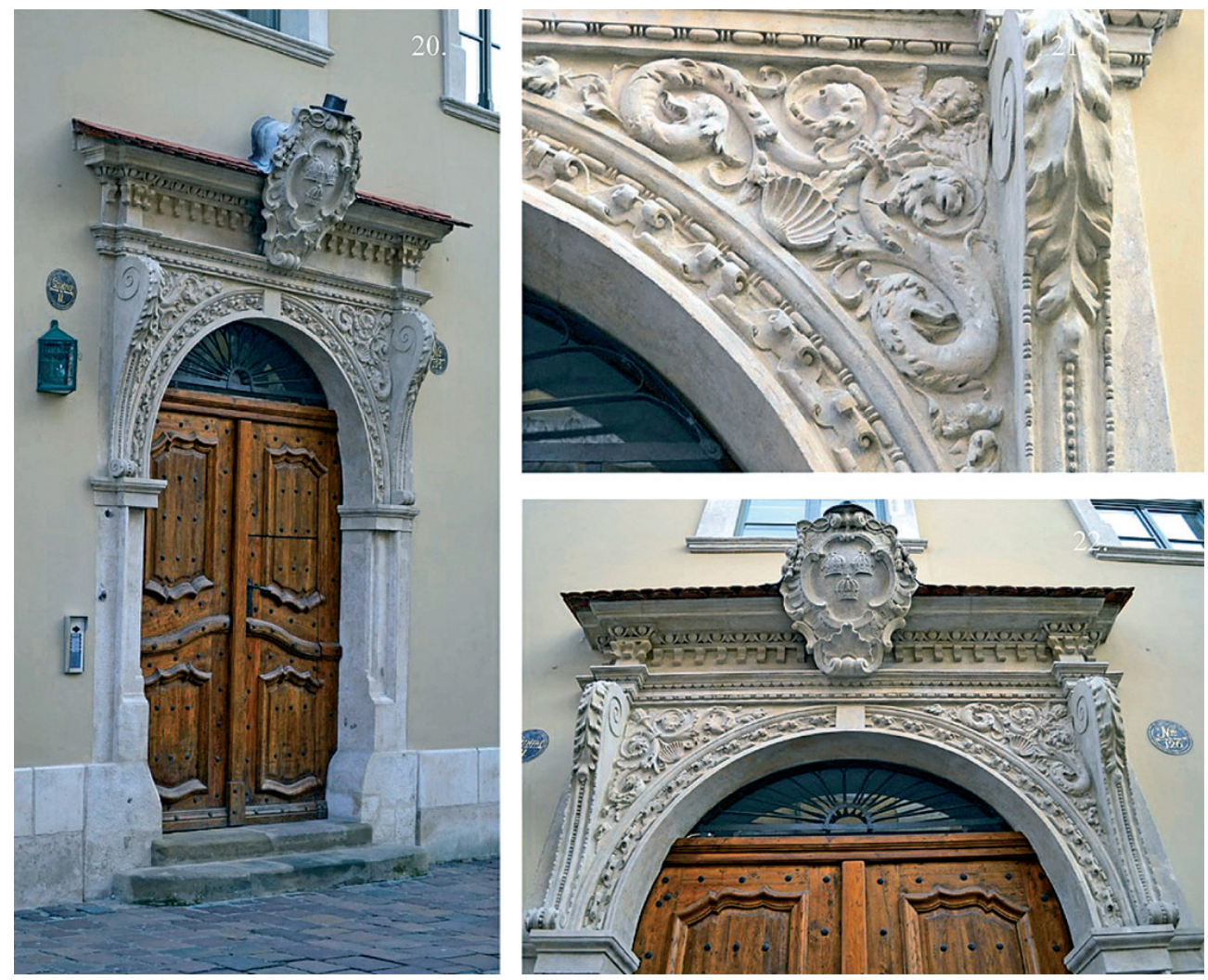

Lintel of a historic tenement house at 18 Kanonicza Street in Cracow

Pic. 20. View of the entire lintel. (Pic. P. Rzęsa)

Pic. 21. Detail in the scrollwerk and ornament of the portal. (Pic. P. Rzęsa)

Pic. 22. View of the volutes. (Pic. P. Rzęsa)

\subsubsection{Tombstone of Urszula Leżeńska in the Elevation of the Holy Cross in Brzeziny}

Signed with the monogram of Jan Michałowicz, the surviving tombstone of Urszula Leżeńska in Brzeziny was carved in its entirety in one type of sandstone material, most probably in the Kunów sandstone between 1563-1568 (Pic. 23). This was the first tombstone in which Jan Michałowicz sculpted a female figure. Due to the mechanical properties of the rock material, the artist was able to produce smooth lines and fine ornamental elements. The artwork was discovered at the beginning of the twentieth century, completely damaged. The sculpture was restored using the anastylosis reconstruction technique, allowing to provide the missing details (among others, two fingers from the right hand) (Pic. 24). The plaque in the upper part of the tombstone was carved in the twentieth century. 

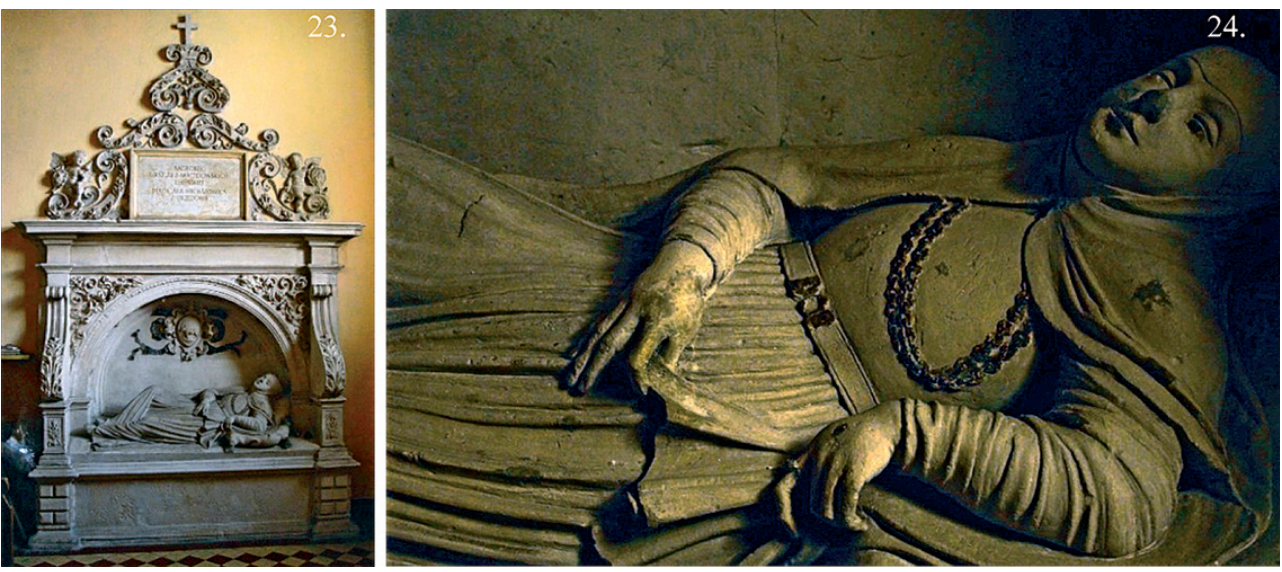

Pic. 23. Tombstone of Urszula Leżeńska in Brzeziny. (Source: https://culture.pl/pl/dzielo/jan-michalowiczz-urzedowa-nagrobek-urszuli-lezenskiej)

Pic. 24. The photo shows restored elements of the monument - two fingers of the right hand. (Source: https://culture.pl/pl/dzielo/jan-michalowicz-z-urzedowa-nagrobek-urszuli-lezenskiej)

\subsubsection{Tombstone of Jan Leżeński in the St. Nicholas church in Chetmno}

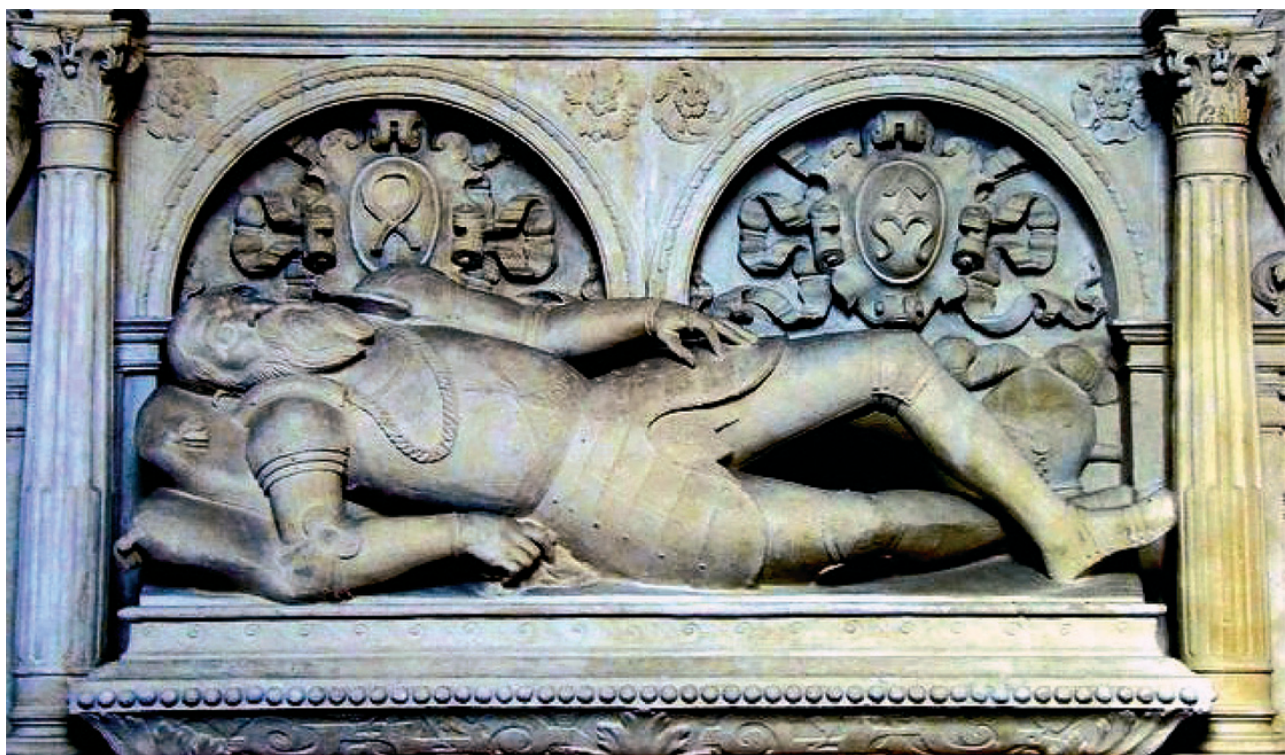

Pic. 25. Tombstone of Jan Leżeński. (Source: http://psbprzedborz.pl/lezenski-jan/)

The non-signed tombstone to Jan Leżeński is very likely to have been sculpted by Michałowicz. This supposition is confirmed by the design which is similar to that of bishop Padniewski's tomb. Carved in the Pińczów limestone, though wrongly referred to as the sandstone (sandstone stays matt limestone and especially the finer-grained limestone of organodetritic origin, not susceptible to polishing), it renders a knight wearing plate armour. 
Analysis of the material showed that fine architectural components, ornamental elements and the figure of Leżeński were all carved in the same stone.

\subsubsection{Tombstone of count Stanistaw Tarnowski and canon Zbigniew Ziótkowski in the Assumption of the Blessed Virgin Mary church in Chroberz}

Inside the parish church in Chroberz, there are two Renaissance tombstones sculpted by Jan Michałowicz: the first monument was made to Stanisław Tarnowski - founder of the church, whereas the second one, much less richly carved (15 years earlier) to Zbigniew Ziółkowski - the then parson. Easy processing and availability of the sculpting material appears to reflect the artist's style. Both monuments have similar ornaments. The colour and not polishing susceptibility, permanence and relatively homogeneous structure of the stone suggest that the basic building material was the Pińczów limestone. Distance of 15 kilometres between Chroberz and Pińczów would account for the use of this raw material.
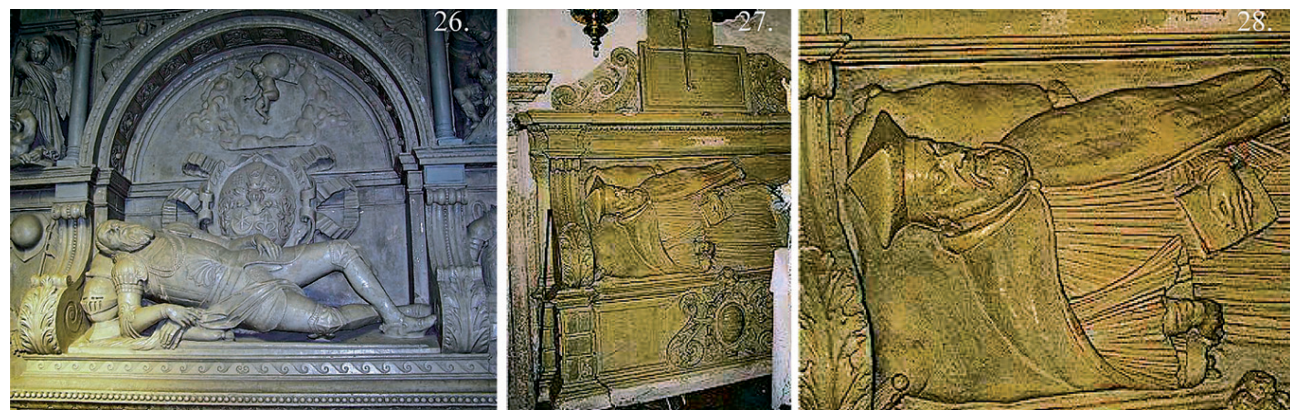

Pic. 26. The central part of Stanisław Tarnowski's tombstone. (Source: http://www.tramp.hg.pl/albumy/chroberz/slides/100 8942.html)

Pic. 27. Tombstone of Zbigniew Ziółkowski. (Source: http://skps.mbz.net.pl/old/skps/chroberz.htm)

Pic. 28. Close-up on the figure of parson Ziółkowski. (Source: http://skps.mbz.net.pl/old/skps/chroberz.htm)

\subsubsection{Epitaphs from the Saint Mary's basilica in Cracow}

1. Epitaph for Jan Leopold, Doctor of Theology, in Saint Mary's church in Cracow, was most probably sculpted by Jan Michałowicz. Arguments for this theory include similar carving method and a style resembling the one used in previous works of the artist. Ornamental elements (corbles, oeil-de-boeufs, flower ornaments) and their arrangement is typical of his style. Significant part of the epitaph was carved in the Pińczów limestone, whereas the plaque with the inscription in the Bolechowice marble.

2. Epitaphs for Girolamo Canavesi and Gabriel of Szadek. Both epitaphs were carved in alabaster, stromatolitic gypsum and anhydrite. They can be found in the cloister of the Dominican church in Cracow. They were made in 1563 (the authors were not able to find photographs of the epitaphs in question). 

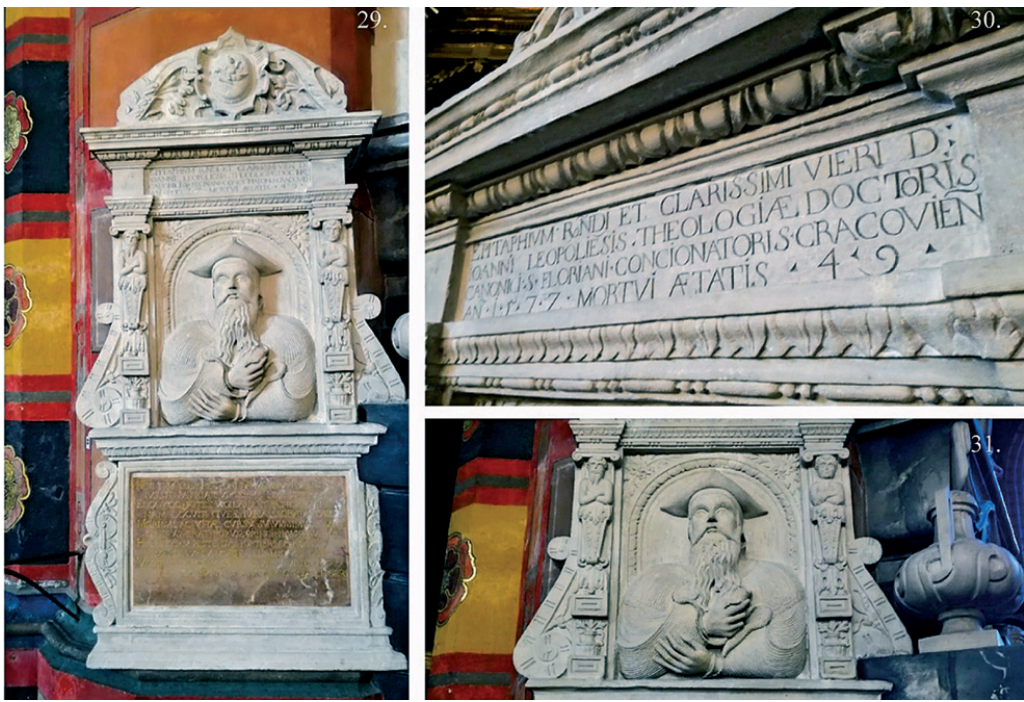

Epitaph to the doctor of theology

Pic. 29. Complete epitaph. (Pic. P. Rzęsa)

Pic. 30. Inscription honouring the person. (Pic. P. Rzęsa)

Pic. 31. Close-up on corble elements found on both sides of the bust. (Pic. P. Rzęsa)

\subsubsection{Tombstone of Wolski brothers in Saint John's Archcathedral (originally, the Beheading of John the Baptist church) in Warsaw}

The original tomb survived until 1944 in the right-hand aisle (Pic. 32). Post-war remains of the tomb were documented in a photograph (Pic. 33). Currently, the plaque saved from war damages and partially restored, is found in the left-hand aisle of the Warsaw cathedral (Pic. 34). Arranged inside the richly carved architectural setting, it had high artistic value. The tomb was most probably carved in sandstone mined in the Świętokrzyskie region; the colour and location of the tomb indicates that the stone could be excavated in the Kunów quarry. The plaque, which failed to survive to this day, was the only exception; most probably it was carved in the Hungarian marble (just as plaques in tombstones of bishop Izdbieński and Zebrzydowski)
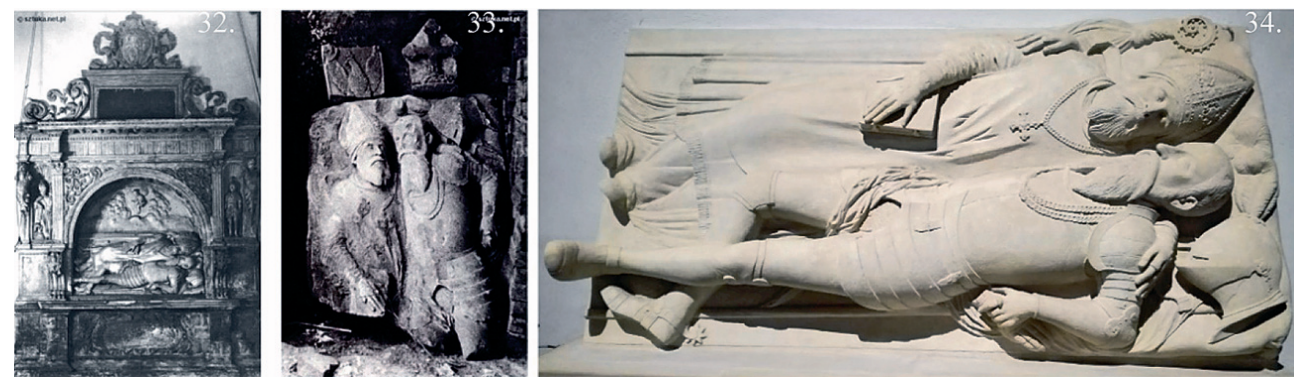

Pic. 32. Tombstone in 1944. (Source: http://www.sztuka.net/palio/html.run?_Instance=sztuka\&amp; PageID=42\&_tytul=sztuka.net\&_obrazek_id=198)

Pic. 33. Post-war remains of the tombstone of Wolski brothers. (Source: http://www.sztuka.net/palio/ html.run? Instance=sztuka\&amp; PageID $=42 \&$ tytul=sztuka.net\& obrazek id=200)

Pic. 34. Plaque from the tombstone of Wolski brothers from 1568 in the Warsaw Archcathedral. (Pic. P. Rzęsa) 


\subsubsection{Ornamental elements found in Arkadia Romantic Park in Nieborów}

In the Romantic Park in Arkadia, established in the late eighteenth century by countess Helena Radziwiłłowa, there are elements from the pulled down furnishings of St. Victoria's chapel in the collegiate church in Łowicz. The interior and exterior of the chapel were entirely designed and sculpted by Jan Michałowicz. Archpriest's Tabernacle (bathrooms), was one of the most original pavilions in the territory of Poland in the eighteenth century. It features Michałowicz-inspired details, such as herms, winged fictitious figures adorned with acanthus leaves, mascarons, rose windows, blind traceries, concise components imitating real landscapes. Inside the building, there are two conspicuous sculptures arranged symmetrically in the arched niche (Pic. 35). Visually, they are identical with sculptures arranged on both sides of bishop Izdbeński's tombstone in Poznań (Pic. 9). Along the south-eastern face of the Archpriest's Tabernacle, there is a wall with incorporated herms (Pic. 36) encased with bog iron. All ornamental elements listed above were made of white sandstone mined in Lower Silesia or Świętokrzyskie region.
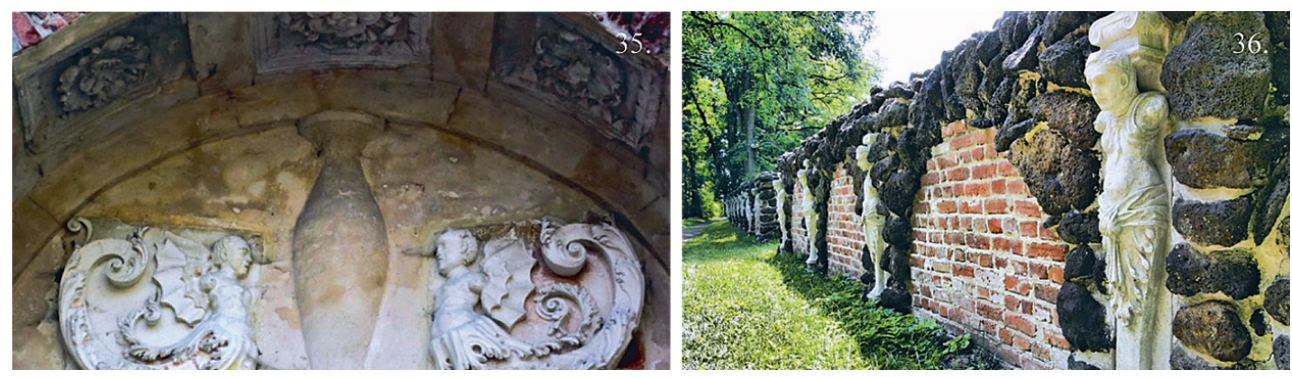

Pic. 35. Sculptures found in the rebuilt St. Victoria's chapel in the collegiate church in Łowicz; currently, they are the components of the Archpriest's Tabernacle. (Source: http://panaszonik. blogspot.com/2014/10/wycieczka-nr-306-arkadia.html)

Pic. 36. The wall with herms chiselled by Jan Michałowicz. (Source: http://gdziebylec.pl/obiekt/pokaz/Przybytek_Arcykap\%C5\%82ana_w_Arkadii/6605)

\section{Summary}

Nowadays, in order to determine whether given rock properties make it useful for specific purposes, the material is examined using relevant test equipment. At the times of Jan Michałowicz, any knowledge in this respect was transmitted by the master to his apprentices, based on the master's experience.

The artist used domestic rock raw materials to sculpt monuments commemorating and honouring important persons who were his contemporaries. At the beginning of his career, he was inspired by works of the greatest masters of his time, who mainly came from Italy, which was reflected in the forms and materials he applied in his own artwork.

He mainly used foreign materials, as artists whose works he imitated, used their domestic materials. In the Renaissance, important persons were initially often commemorated with monuments carved in the Hungarian marble, also referred to as the royal marble, due to its colour and pattern. However, the cost of acquisition, transport from faraway destinations, as well as political situation, that is the conquest of the Kingdom of Hungary by the Ottoman Empire, made artists resign from foreign materials and successfully look for the domestic ones. In his works that managed to survive intact or which were modified in the centuries that 
followed, Jan Michałowicz clearly favours the local stone, most often mined in quarries in the Świętokrzyskie region. For the petrographic analysis, the authors selected the most distinguishable works of the artist, which he signed or which are most likely to have been sculpted by him. The authors analysed the materials used by the artist to carve specific elements of his works, as well as rock raw materials in terms of their historical and contemporary properties. Consequently, the petrographic study allowed to describe the rocks in greater detail, as well as their properties useful for sculpture purposes, and their durability. Artistic qualities such as the colour, pattern and appearance of the stones many decades after their processing are also significant, as they helped determine the sources of stones used by Jan Michałowicz during his specific projects. These include the quarries near Pińczów (limestone), Kunów (sandstone), Bolechowice (marble), Żurawno (alabaster) and initially quarries in Hungary.

The discussed works of Jan Michałowicz from Urzędów provide firm grounds for acknowledging the artist as the leading and uncommon contributor and co-founder to Polish Renaissance art.

\section{References}

[1] Blumówna H., Bochnak A., Ciołek G., Dobrowolski T., Dutkiewicz J. E., Herbst S., Hornung Z., Lepiarczyk J., Mańkowski T., Mole W., Niemojewski L., Piwocki K., Sawicka S., Szablowski J., Tatarkiewicz W., Tołwiński T., Zachwatowicz J. Historia sztuki polskiej, Tom II Sztuka Nowożytna, część piąta, Sztuka renesansowa i manierystyczna 1500-1650, Wydawnictwo Literackie Kraków, Kraków, 1962.

[2] http://urzedow.pl/historia/postacie/biografie/michalowicz.htm.

[3] Praca zbiorowa pod redakcją Elżbiety Przesmyckiej, Architektura sakralna w ksztaltowaniu tożsamości kulturowej miejsca, Wydawnictwo Politechniki Lubelskiej, Lublin 2006

[4] Procyk W. Marmury królewskie - problematyka badań i metody konserwacji, Ochrona Zabytków 54/3 (214) (2001) 252-264.

[5] Płuska I., Rębiś M., Smoleńska A. Kamień w architekturze i dekoracji Kaplicy Zygmuntowskie, Biuletyn Historii Sztuki 67(1-2) (2005) 144-156, 160-161

[6] Mizerski W., Orłowski S. Geologia historyczna dla geografów, Wydawnictwo PWN, 2005.

[7] Osika R. Budowa geologiczna Polski. Tom IV. Złoża surowców mineralnych, Wydawnictwa Geologiczne, Warszawa, 1987.

[8] Wardzyński M. Między Ilalia i Niderlandami. Środkowoeuropejskie ośrodki kamieniarsko- rzeźbiarskie wobec tradycji nowożytnej. Uwagi z dziedziny materiałoznawstwa., Warszawa, 2009.

[9] Kiełczewska J. Świętokrzyskie marmury i wapienie - maty przewdnik po polskich zabytkach, cz.1, source: http://www.surowce-naturalne.pl/strona/swietokrzyskie-marmury-i-wapienie- $\% \mathrm{E} 2 \% 80 \% 93$ maly-przewodnik-po-polskich-zabytkach-cz-i, 2013.

[10] Kozłowski S. Surowce skalne Polski, Wydawnictwa Geologiczne, Warszawa, 1986

[11] Myśliwiec M. Mioceńskie skaty zbiornikowe zapadliska przedkarpackiego, Wydawnictwo Przegląd Geologiczny, 52(7) (2004).

[12] Bromowicz J., Figarska-Warchoł B. Kamienie dekoracyjne i architektoniczne eksploatowanych złóż Polski południwo - wschodniej, Prace Naukowe Instytutu Górnictwa Politechniki Wrocławskiej. Studia i Materiały, 132(39) (2011).

[13] Śliwa T. Mioceńskie alabastry z zapadliska przedkarpackiego - występowanie i zastosowanie, Geologia, 35(2/1) (2009) 87-94.

[14] Kiełczewska J. Świętokrzyskie piaskowce - mały przewodnik po polskich zabytkach, cz. 2, 9, source: www.surowce-naturalne.pl, 2013.

[15] Kozakiewiczowie H. i S. Renesans w Polsce, Wydawnictwo „Arkady”, Warszawa, 1976. 
[16] Zlat M. Sztuka polska, Tom III Renesans i manieryzm, Wydawnictwo „Arkady”, Warszawa, 2008, 2010.

[17] Wardzyński M. Import i zastosowanie „czerwonych” marmurów w małej architekturze i rzeźbie w Rzeczypospolitej od XIV do I połowy XVII w., Instytut Historii Sztuki Uniwersytetu Warszawskiego, electronic publication, pp. 12, 27 il., (cf.) http://www.fundacja-hereditas.pl/portal/kamien.php?idt $=6$

[18] Wardzyński M. „Alabastry ruskie” - eksploatacja i zastosowanie w matej architekturze i rzeźbie na Rusi, w Koronie i na Ślasku w XVI wieku, [in:] Między Wrocławiem i Lwowem. Sztuka na Ślasku, w Małopolsce i na ziemiach ruskich Korony od XVI do XVIII wieku, red. A. Betlej, K. Brzezina i P. Oszczanowski, Wrocław 2010, pp. 339-358, 14 il., tabl. LXII-LXIII.

[19] Rożek M. Przewodnik po zabytkach Krakowa, Wydawnictwo WAM, Kraków, 2006.

[20] Kozłowski K. Petrografia skat metamorficznych, Uniwersytet Śląski, Katowice, 1978.

[21] Łydka K. Petrologia skał osadowych, Wydawnictwa Geologiczne, Warszawa, 1985.

[22] Tomaszewska-Szewczyk A., Alabaster jako tworzywo rzeźbiarskie, przykłady wystęujących zniszczeń oraz propozycja metod konserwacji, Księga pamiątkowa ofiarowana Profesorowi Wiesławowi Domasłowskiemu pod red. B.Soldenhoff, Torun, 2002.

[23] http://psbprzedborz.pl/lezenski-jan/. 